Bryn Mawr College

Scholarship, Research, and Creative Work at Bryn Mawr College

1993

\title{
Socrates' Aspasian Oration: The Play of Philosophy and Politics in Plato's Menexenus
}

Stephen G. Salkever

Bryn Mawr College, ssalkeve@brynmawr.edu

Let us know how access to this document benefits you.

Follow this and additional works at: http://repository.brynmawr.edu/polisci_pubs

Part of the Ancient Philosophy Commons, and the Political Science Commons

\section{Custom Citation}

Salkever, Stephen G. "Socrates' Aspasian Oration: The Play of Philosophy and Politics in Plato's Menexenus." American Political Science Review 87 (1993): 133-143.

This paper is posted at Scholarship, Research, and Creative Work at Bryn Mawr College. http://repository.brynmawr.edu/polisci_pubs/12

For more information, please contact repository@brynmawr.edu. 


\title{
SOCRATES' ASPASIAN ORATION: THE PLAY OF PHILOSOPHY AND POLITICS IN PLATO'S MENEXENUS
}

\author{
STEPHEN G. SALKEVER Bryn Mawr College
}

$\mathrm{P}$ lato's Menexenus is overlooked, perhaps because of the difficulty of gauging its irony. In it, Socrates recites a funeral oration he says he learned from Aspasia, describing events that occurred after the deaths of both Socrates and Pericles' mistress. But the dialogue's ironic complexity is one reason it is a central part of Plato's political philosophy. In both style and substance, Menexenus rejects the heroic account of Athenian democracy proposed by Thucydides' Pericles, separating Athenian citizenship from the quest for immortal glory; its picture of the relationship of philosopher to polis illustrates Plato's conception of the true politikos in the Statesman. In both dialogues, philosophic response to politics is neither direct rule nor apolitical withdrawal. Menexenus presents a Socrates who influences politics indirectly, by recasting Athenian history and thus transforming the terms in which its political alternatives are conceived.

T he Menexenus is one of the Platonic dialogues least read by students of political theory. But there are good reasons, both thematic and stylistic, for us to consider the dialogue more carefully than we have in the past. This is the dialogue in which Socrates recites to a young and admiring friend named Menexenus a political speech that he says he has learned from Pericles' mistress Aspasia, whom he describes as his, as well as Pericles', instructor in the art of oratory (235e3-7)-a funeral oration (epitaphios) for the Athenian war dead. ${ }^{1}$ The dialogue can be divided into three parts: (1) an opening conversation between the two men (234a-36d); (2) the epitaphios proper $(236 d-49 c)$, which is subdivided into three parts (a historical account of the people and the politeia (regime) of Athens, a narrative of Athenian war deeds from antiquity to the present, and an exhortation to present-day Athenians); and (3) a brief closing exchange between Socrates and his interlocutor (249d-e).

Aspasia, Socrates tells Menexenus, has "glued together" the speech partly, as it seems to him, with "leftover" bits from her composition of the famous funeral oration delivered by Pericles (236b1-6). ${ }^{2}$ The Menexenus, then, presents itself as Plato's Socratic counterpart to the speech of Thucydides' Pericles. In both speeches we have an account of the deeds of the Athenian past combined with an account of the essential character of the Athenian politeia, both seemingly designed to throw light on how Athenians are to understand themselves and to act in the future. But the styles of the two discourses are not similar: Thucydides gives us the speech of a statesman he admires, a speech that could to all appearances have been delivered in Athens; ${ }^{3}$ while there can be little doubt that Socrates' Aspasian epitaphios and the brief exchanges with Menexenus that precede and follow it make up a comic commentary on the Athenian funeral oration, though in exactly what way and to what end we cannot be sure.

In the Menexenus, then, Plato elaborates the contest he establishes in the Gorgias between Pericles and Socrates for the right to be called the true Athenian politikos (statesman). Moreover, the dialogue suggests the possibility of redeeming what in the Gorgias seems unredeemable: ${ }^{4}$ the practice of public oratory in democratic Athens. The funeral speech itself in places appears to be an alternative to Pericles' epitaphios, rather than comic commentary on it, particularly in its characterization of the Athenian politeia as an aristocracy-by-popular-consent (238c7-d2), rather than a democracy, and its advice to both the fathers and the mothers of the war dead to turn their attention inward and concern themselves with their own virtue (247e5-48a7), rather than to fall in love with Athens. Thus, even though the long and detailed military history of Athens from the Persian War to the present that occupies over half of the epitaphios in the Menexenus (239d1-46a3) is chock-full of errors, omissions, and hyperbole and even though the dialogue's opening and closing conversations are insistently playful and ironic, the speech also presents a picture of good Athenian citizenship that seems plausibly Platonic or Socratic. ${ }^{5}$ Socrates' recitation of Aspasia's patchwork epitaphios thus opens the possibility that there is an alternative to the rhetoric of flattery and the politics of collective pleonexia (unbounded desire) condemned in the Gorgias. This is surely a question of the utmost seriousness; yet Plato's treatment of it here is playful and ironic. ${ }^{6}$ How can this be so?

Commentators on the Menexenus have been sharply divided over the question of whether to read the dialogue as a serious epitaphios or as an ironical comment on Athenian politics in general and the institution of funeral orations in particular. ${ }^{7}$ Either way, a Platonic dialogue concerning epitaphioi must command our attention, since there is good reason to think that the institution of the public funeral oration had a special place in Athenian political oratory, as the occasion on which Athenians gathered not only to hear a eulogy on the war dead but to recall who 
they were as Athenian citizens. Lincoln's Gettysburg Address is the closest American equivalent-both a eulogy and an exercise in collective self-definition. But Lincoln's speech was an unusual event, while the public funeral oration was a long-standing and customary practice in Athens. ${ }^{8}$ According to Nicole Loraux's (1986) detailed study of the epitaphios, its function was to provide the occasion on which Athens was invented and reinvented in narrative form. Only a few such orations have come down to us; surely the most famous is Pericles' speech in Thucydides, which is the classic statement of the ethos of Athenian citizenship at the height of its fifth-century flowering. Two others, by Demosthenes and Hyperides, are from later in the fourth century; a speech written by Lysias appeared roughly 10 years earlier than the Menexenus, and there is a small fragment from an oration by Gorgias. Even though the number of examples is small, it is clear that the epitaphios was a distinct genre, ${ }^{9}$ with standard expectations about the ordering of topics and the contents of the message. In the Menexenus, Socrates follows the formal order of the epitaphios-a prelude identifying the speech as one required by Athenian nomos (law or custom), a praise of the dead heroes and of Athens, and a consolatory exhortation (paramuthia) to the living-but criticizes the message of other funeral orations and provides an alternative way of characterizing Athenian virtue. Thus, the dialogue appears to contain both a Socratic critique of Athenian selfunderstanding (along the lines set out in the attack on Pericles and traditional Athenian politics in the Gorgias) and an alternative to that self-understanding. Here we have the philosopher speaking not to the city but to his city-and in a language and form the city understands considerably better than the language of Socratic dialogue and elenchos (refutation). The dialogue gives us the Platonic Socrates acting the role he claims for himself in the Gorgias: the one Athenian who truly practices genuine politike (statecraft), the one artful politikos in Pericles' city.

But any attempt to ascertain the meaning of the dialogue is radically unsettled by the density and variety of its irony-both Platonic and Socratic. This is, I think, the primary reason why the Menexenus has not been treated as a central work in the Platonic corpus. Part of the problem is the difficulty of deciding what it means to say that the dialogue is ironic. Most of those who see the Menexenus as ironic, rather than serious, characterize that irony either as a rambunctious parody on the model of Aristophanic comedy, designed to deflate the arrogant pretension of Athenian political speech, ${ }^{10}$ or as bitter satire intended to expose the hypocrisy and injustice of the democracy that murdered Socrates and scorned philosophy. ${ }^{11}$ But reference to one or the other of these genres-parody or satire-is not sufficient to account for the complex tone shifts of Socrates' playful speech or for the subtlety and essential ambiguity of Plato's written dialogue. Recognizing this, some commentators urge that the core of the dialogue is serious. ${ }^{12}$ But the nature of Platonic and Socratic "seriousness" here, as with their "irony", requires more careful consideration than it has so far received. Those who deny that the dialogue is primarily ironic generally understand it to be promoting some particular program of reform for Athenian politics. But there is no clear political program or set of principles to be found in the dialogue-no systematic "theory" in the sense used by contemporary analytic philosophers. In order to make sense of the Menexenus, we must first reject the idea that the dialogue has to fall into one of two mutually exclusive genre categories: the comic or the serious.

My alternative to the humorous/serious antithesis is to say that the dialogue is a playful comment on one of the most solemn moments of Athenian politics and that its commentary is not merely negative and dismissive but carries with it some opinions as to how to think about the possibilities and limits of democratic politics. The playfulness of the commentary resides not in its failure to affirm any opinions about politics as true but in its refusal to accept any formulation of even the most dearly held opinions as final, as written in stone. ${ }^{13}$ The Platonic and Socratic opinions playfully yet seriously asserted by the Menexenus involve several aspects of political life; but they always appear to oppose views expressed or implied by Thucydides and by his model of democratic leadership, Pericles. ${ }^{14}$ The central instances of this opposition between Plato's politics and Thucydides' are five. First, in what terms should political life be evaluated? For Thucydides and Pericles, the key standards are those of greatness and splendor. Socrates says that the standard for evaluating regimens is set by the example of nurturing nature and by the image of good-not great or noble-human beings (238c). Second, what kind of historical selfunderstanding is appropriate for democratic Athens? Thucydides' Peloponnesian War is a monumental history in which nature and the gods play no part but that of resistances to be overcome ${ }^{15}$ and in which Athens is shown creating itself through its daring in wars both defensive and expansionist. Socrates, by contrast, provides a mythic and theocentric story of the origin of the city and follows it with a jumbled, false, and largely chaotic record of recent Athenian wars and battles. Third, what questions should most concern Athenian citizens? Pericles asks his listeners to consider how best to maintain the collective civic project of dynamic Athenian rule. Socrates ignores all collective enterprises and instead emphasizes here, as in the Apology, the question of the virtue of each individual and the importance of caring for oneself and for one another. Fourth, what is the appropriate vocabulary of political speech? Thucydides' vocabulary is dominated by terms for greatness, glory, brilliance, and action. Plato in this dialogue, as elsewhere, employs prominently and with particular significations terms like epimeleia, therapeia, technē, phusis, aretē, dikē, and eleutheria (roughly-caretaking, healing, art, nature, virtue, justice, and freedom). Fifth, what is the appropriate tone in which to consider political matters? Pericles' tone is one of consis- 
tent gravity and severity, and Thucydides employs the tragic device of juxtaposing sharply contrasting moments of elevation and wretchedness, as in the abrupt transition from Pericles' epitaphios to the account of the plague. Plato's taste runs to a light, playful, frequently shifting tone.

On my reading, then, the Menexenus should not be reduced either to parody or satire on the one hand or to a systematic theoretical treatise or a practically plausible Athenian epitaphios ${ }^{16}$ on the other but should be understood, instead, as a playful reflection designed to provide a starting point for thinking about the kind of public speeches that ought to be made in democratic Athens and polities like it. ${ }^{17}$ In trying to assess the meaning of the Menexenus, it is crucial not to exaggerate some central Platonic distinctions or tensions (e.g., philosophy/politics, mythos/logos [see Phaedrus and Gorgias], and serious/ playful) by assuming that the weight of the dialogue must fall into one or another of each pair. Hence, it is misleading to ask whether the dialogue is on the side of the polis or of philosophy, serious or playful, expressive of Plato's serious political views or an attempt to subvert Athenian politics. Part of Plato's literary practice is to show us how the philosopher can also be a true politikos, how a mythos can be a logos, and how the complex ironies of an artfully written dialogue illustrate serious play. The dialogue can then be seen as a prime example of the kind of political activity indicated by the Eleatic Stranger's depiction of the politikos as a master weaver who operates behind the scenes of public life in the Statesman: Socrates in Menexenus is shown away from the public world of the agora, trying to weave together the strands of gentleness and virility, of the female and foreign (Aspasia) and the male and native (Menexenus). ${ }^{18}$

\section{THE SETTING OF THE DIALOGUE: CHARACTER AND CONCEALMENT}

The dramatic date of the dialogue-fixed by reference to events in the Corinthian War down to the Peace of Anatalcidas (245d6-246a1) and hence immediately obvious to Plato's contemporaries-is at the earliest 387 B.C. and thus years after the deaths of both Socrates and Aspasia. (The dating is thus even more anachronistic than the Gorgias. ${ }^{19}$ ) Plato writes a dialogue that in effect identifies itself from the outset as a fiction, as a Platonic invention. The reader cannot believe even in the approximate historical accuracy of the dialogue; this is Socrates made young and fair with a vengeance. ${ }^{20}$ As for Socratic irony within the dialogue, the character Socrates presents the logos he recites-his version of that most Athenian of speeches-as having been written by "Aspasia the Milesian" (249d-2), a female foreigner. Nevertheless, Menexenus and the readers of the dialogue cannot be sure whether Socrates may not have invented the story of Aspasia's authorship in order to conceal his own hand in its production. At the end of the dialogue, he tells Menexenus that he will be happy to tell him many other fine Aspasian political logoi so long as Menexenus swears to keep their origin a secret (249e3-5).

The stress on disguise runs even deeper: the longest part of Aspasia's (Socrates', Plato's) epitaphios, and the section in which the speech draws conclusions from its narrative history of Athens concerning how present-day Athenians ought to live their lives, is a prosopopoeia of the war dead (something not found in the other funeral orations). The central practical conclusions of the speech are placed in the mouths of the dead heroes. The dialogue thus presents itself as a work of manifold invention and concealment. Plato invents Socrates, who may or may not invent a speech-writing Aspasia, who in turn invents a unison chorus of dead Athenians. Socrates' Aspasia underlines her own artful inventiveness here by saying that she will "say to you now both the things that I heard from them then and those which they would be pleased to speak now if it were possible, basing my conjecture on what they said then. But you must believe that you are hearing from them themselves the message I will give you" (246c4-8). This most political of Platonic dialogues is also perhaps the most complexly ironic; my argument here is that the pairing of political theme and ironic style is no coincidence.

But what does this irony signify? If we rule out, as I think we must, treating the dialogue as either deflating parody or bitter satire, we are left with two elements crucial to Platonic/Socratic irony (crucial in that these are essential aspects of their practice of philosophy): (1) dissimulation or concealment and (2) ambiguity. Irony both conceals the intentions of the speaker and calls attention to the ever-present possibility of linguistic ambiguity. This style suits the practice of Platonic and Socratic philosophical politics in two ways: (1) because the work of the philosophical statesman is not to design institutions, laws, or policies but to persuade citizens of the primacy of the question of the good life or of human arete, over the questions of power, security, and honor; and (2) because the central business of such a statesman is to insist upon the unending importance of asking this question by refusing to give unqualified acceptance to any formulation or doctrine that purports to solve it once and for all. The philosopher's contribution to democratic politics is to place a question on democracy's agenda and, through insisting on the essential ambiguity of language, immunizing democrats against accepting any rule or formulation as final and absolutely binding or correct. There are two principal rhetorical problems to be solved here by the philosophical politikos: one is that of finding a way to introduce philosophy into politics without philosophy's undergoing a corrupting transformation into sectarianism; ${ }^{21}$ the other is that of giving political advice without calling excessive attention to the philosopher's view that the philosophic life is different 
from, and better than, the political life..$^{22}$ Let us see how the Menexenus carries out this work.

\section{THE OPENING DIALOGUE (234A-236D)}

The meeting between Socrates and his well-born and politically ambitious young Athenian friend is private. Although we are not told the location of the dialogue, the conversation is initiated by Socrates, who encounters Menexenus as the latter is leaving the agora coming from the Bouleterion, the chamber housing the Council of Five Hundred, ${ }^{23}$ where that body is about to select a speaker to deliver the traditional epitaphios for the Athenian war dead. ${ }^{24}$ The location of the dialogue thus blurs the bright Periclean line between the private and the public worlds. The first words of the dialogue are Socrates' question "Ex agoras e pothen Menexenos?," "Do you come from the agora or where, Menexenus?" (Socrates being outside the "precinct of public life"), ${ }^{25}$ and the answer, "Yes, from the agora, from the Bouleterion, Socrates." We are told by Socrates that the two mean are quite alone and that it is only because they are alone that Socrates is willing to recite the epitaphios to Menexenus (236c11-d3). The question why Socrates wants to speak to Menexenus is answered in the exchange between the two immediately following:

Socrates. And why especially were you at the Bouleterion? Or is it clearly because you think you have got to the end of paideia (education) and philosophia, and thinking you have grasped these things sufficiently, you are ready to turn your mind to greater things, to try your hand at ruling (archein) us older folk in spite of your age, o amazing man, so that your family might never fail at providing us with a caretaker (epimelètess)?

Menexenus. With your permission and counsel, Socrates, I am eager to rule (archein); otherwise, not.

This exchange ${ }^{26}$ establishes the dialogue as one between a philosopher and a decent young member of the Athenian political class, one who assumes his future will be occupied with ruling, though only with the consent of others. Menexenus is not a future tyrant. Socrates does not attempt to dissuade Menexenus but, rather, tries to redescribe the political life form its ordinary Athenian designation (archein and ruling) to Socrates' characteristic and different way of speaking about political leadership (epimeleia, the art of caretaking). Similar redescriptions of ruling or acting as caretaking or something like it form an important aspect of Socrates' hidden political paideia in several dialogues. In the Meno, for example, Meno's first definition of virtue is that the virtue of a male is "to act (prattein) on behalf of the city, acting so as to do well to friends and harm to enemies" (71e1-4). Nearly two pages later, Socrates "reminds" Meno of his definition: "Didn't you say that the virtue of a male is to manage (diokein) the city well?" (73a6-7). Like Socrates' concealed redescription of praxis (action) as management in the Meno, we may expect that his conversation with Menexenus is aimed at transforming the latter's way of thinking about political life from a focus on maintaining a position of leadership in democratic Athens to a consideration of how properly and artfully to care for human beings. This expectation is fully confirmed by the last exhortative section of the epitaphios itself, which repeatedly calls on the city to exercise care toward all (e.g., 249c2-3) and on each Athenian citizen to serve and be served in turn (therapeuein te kai therapeuesthai, 249c5-6). To the extent that Socrates has gained control over the terms of Athenian political discourse here, the point of the epitaphios lies in its transformation of the political world as conceived in speeches from a scene of praxis and archē (rule) to one of therapeia and epimeleia.

The very end of the dialogue is a parting exchange in which Socrates playfully insists, and Menexenus accepts, the need to maintain secrecy about this conversation and other similar ones they may have in the future. (Socrates says he will tell Menexenus many other fine political speeches.) In the frame dialogue of the Menexenus (236c-d), Socrates presents himself as wanting to hide the epitaphios he has heard from Aspasia - at first because of his fear that Aspasia will be angry with him if she discovers he has revealed the speech and a moment later because he fears Menexenus will laugh at him, taking Socrates for an old man still playing like a child. Finally, Socrates says he will gratify Menexenus, since they are alone. His desire to gratify him is, he says, such that he might even strip naked and dance, if that is what it took. This figure of the teasingly reluctant philosopher is familiar from the Republic. The depth of the transformation of Athenian political self-conception Socrates aims at is both concealed and underscored by his coy aloofness. The very fact that Socrates has no desire for political power gives his words a power they might otherwise lack.

After learning that the business Menexenus observed at the Bouleterion concerns the selection of a citizen to give an epitaphios, Socrates' first response is to remark on how kalon (beautiful), in many ways, it is to die in battle, since no matter how worthless you were when alive, you are sure to get a magnificent send-off by speakers who, like wizards, bewitch our souls (235a2). Not only do these orators praise the Athenian dead (worthless though they may have been), but they praise Athens itself in every way, as well as the living citizens and all their ancestors. There is such a riot of patriotic encomium, Socrates says, that for more than three days (235b8-c1), he feels himself to have become bigger, better born, and more beautiful (meizōn kai gennaioteros kai kalliōn) than he was before (235b2). Greek foreigners (xenoi), who, Socrates says, he almost always has with him on such occasions, are likewise bewitched and view Socrates as more august (semnōteros) and Athens as more amazing (thaumasiōtera) than before (235b2-8). For as long as the orator's words ring in the ears of the audience, Athenians and Athens are puffed up in their own eyes and in those of the watching world. ${ }^{27}$

"You are always making fun (prospaizeis) of the orators, Socrates," Menexenus responds (235c6); 
and, of course, Socrates is playing. But the words of Socrates' playful speech not only ridicule the orators but call attention to the way his own auditors respond to Socrates, who can also be charged with wizardry for inducing not a feeling of puffy superiority (semnōtes, 235b8) ${ }^{28}$ but a sense of bafflement (aporia). This effect of Socratic logos is noted not only by menacing foreigners like Meno and local enemies like Anytus $^{29}$ but in the description of a very Socratic form of paideia described by the Eleatic Stranger in the Sophist (230e-31a). At its best, Socratic elenchos and aporia is designed to get interlocutors to become more gentle to others and more angry with themselves, more determined to inquire about what sort of life they should be leading. There is thus a direct confrontation: the semnos logos (august discourse) of the patriotic epitaphios as depicted by Socrates removes the problem the aporetic logos (baffling discourse) seeks to make pressing. As Pericles says in his epitaphios in Thucydides, all that is necessary to achieve virtue, if you are male, is to allow yourself to fall in love with Athens in her imperial greatness and if you are female, to stay at home and out of the way $(2.43,51)$. But at the same time, the aporetic logos refuses to present solutions and so seems to leave its victims, even those who love Socrates, no choice but to repair to the orators-as Cleitophon repairs to Lysias and Thrasymachus (Cleitophon, 410c6-8). The introductory dialogue of the Menexenus thus sets up this question: Is there any way that the Socratic politikos can meet the political orators on their own ground? $?^{30}$

Following Socrates in the Gorgias, we might put the question this way: Is there a way of speaking to the Athenian demos that unlike the speeches of Pericles, will orient individual members of the demos toward the question of their own virtue, of whether they are sufficiently just and moderate, and not toward the civic projects of "building harbors and dockyards and city walls, and of exacting tribute from subject peoples, and similar nonsense (phluaria)" (Gorgias, 519a14)? The ironic epitaphios of the Menexenus is a kind of answer to that question.

\section{THE EPITAPHIOS, PART 1: THE GENEALOGY AND CHARACTER OF THE ATHENIAN POLITEIA (236D-39A)}

After acknowledging the Athenian nomos (law) that establishes the public funeral oration and after noting (except for Socrates) $)^{31}$ the difficulty of finding words adequate to memorialize deeds of such valor, the funeral orators all open by describing the origin and character of Athens. Emphases differ among the different speakers, but the differences between Socrates and Pericles are especially striking. Unlike other speakers, Pericles spends very little time on the Athenian genos, or race (Ziolkowski 1981, 75). What matters most to him about Athens is not the ancient race from which the Athenians among his audience are descended ${ }^{32}$ nor even the political freedom that the remote ancestors established but the deeds of the past fifty years that have founded and expanded the Athenian Empire (Thucydides 2.36.2). He does note that the same race of Athenians has lived on the same land of Athens, but this is only in passing and he draws no practical conclusions from it.

Socrates' emphasis in his discussion of the Athenian heritage is in striking contrast to Pericles'. He begins by saying that in praising the war dead, we ought to proceed according to nature (kata phusin), just as the dead derived their goodness from nature (237a). Socrates' repeated stress on the importance of nature as a source of goodness (Athenians are unusually eugeneia [of good blood] [237a6-7] and that is the first thing we should praise about them) and standard of evaluation stands in sharp opposition to the stress on the extraordinary daring and drive of fifthcentury Athenians displayed in Pericles' oration and elsewhere in Thucydides. ${ }^{33}$ Socrates' speech dwells on the legend of Athenian autochthony, celebrating the fact that Athenians, unlike other people, both sprung from, and were nurtured by, the land they live on today-Athenians are blessed by sharing both a fatherland and a nourishing mother earth (237c5d2) ${ }^{34}$ Not only are the Athenians autochthonous, but Athens has been unusually beloved of the gods-so much so that while all the rest of the earth was full of wild animals, the Athenian earth alone brought forth only human beings and human food: wheat, barley, olives. Not only that, but the earth, having supplied material nurture for her Athenian children, finds them gods to educate them, "gods whose names it is fitting for us to omit here, for we know them, gods who established our way of life, in our daily regimen educating us in the technai first of all, and then concerning guarding the land teaching us how to acquire and use weapons" (238b2-6).

All this ridiculously inflates the specialness of Athens, to be sure, so that no reader could think that Socrates' Aspasian epitaphios aims at giving an accurate, or even a believable, history of the origins of Athens. But the speech does more than ridicule patriotic fervor. Socrates' comic genealogy makes the greatness of Athens depend on the good fortune of her natural origin and on divine favor, not on the special bravery of Athenian men of war. While Pericles' civic encomium says nothing about the natural setting of the city of Athens and nothing at all about the gods, ${ }^{35}$ Thucydides in his own voice speaks of the causes and advantages of Athenian autochthony in a way that is diametrically opposed to the Socratic account: "Attica, because of the barrenness of its earth, was for the most part free from stasis (civil strife) and therefore always inhabited by the same human beings" (1.2.5-6). There was nothing in the natural setting of barren Athens to attract invaders, so that the race of Athenians acquired unity because of the poverty, rather than bounty, of their natural inheritance. For Socrates, this nature represents an inheritance to be treasured; for Thucydides, a weakness to be overcome. The glory of Athens, for Pericles 
and Thucydides, is in all respects strictly manmade; for Socrates, love of country is expressed by a playful gratitude to the earth and the gods.

Born from the earth and educated by the divine teachers their mother chose for them, Socrates continues, the ancestors of the war dead set up a politeia, which should be briefly recalled. Just as Socrates prefaces his story of autochthony with the statement that a good epitaphios must praise the dead kata phusin, here he begins his discussion of the Athenian regime with a general definition: "A politeia nourishes human beings (politeia gar trophē anthrōpōn esti); it is noble when it nourishes good humans and the reverse when it nourishes wretches (kakoi)" (238c1-2). To show the nobility of a regime, it is necessary to show that it produces good human beings. Since Socrates has already told Menexenus that Athenian funeral orations praise wretches (phauloi) along with good men (234c), it would appear difficult to show this for Athens; and Socrates does not even try. Instead, he goes on to characterize the Athenian politeia as one that is called by some a democracy "but is in truth an aristocracy with the approval of the many (met'eudoxias plèthous aristokratia)" (238d1-2). In Athens, the speech continues, political power is held most of the time by the people (plèthos); but at times, the people give power and rule to those citizens who seem to them to be the best. In Athens, unlike other cities, no one is chosen for office because of his wealth or parentage but because he seems wise and good. Socrates never says here that the Athenians do, in fact, choose the wisest and best to rule but only that the regime requires elections for office, which are determined by the opinion of the majority, not by the status of the candidates. The basis for the regime of the best-in-the-opinion-of-the-many is located in the nature of Athens. All other cities are heterogeneous collections of all sorts of people. As a result in those cities, whether they are tyrannies or oligarchies, the citizens regard each other as slaves or masters: "But we regard each other as brothers born of a single mother, and so do not think ourselves worthy to be each other's slave or master, but our natural equality of birth makes it necessary for us to seek conventional legal equality (hē isogonia hèmas he kata phusin isonomian anagkazei zètein kata nomon)" (239a1-2).

None of this recants the often-expressed Socratic view that Athenian democracy generally makes wrong choices about who are its best citizens. In fact, it raises the question of whether those who have seemed wisest and best to the Athenians in the past really have been the wisest and best. Nor is Socrates' contention that the Athenian regime aspires to be an aristocracy, rather than a democracy, incompatible with his critique of Athenian practice elsewhere. ${ }^{36}$ Thus, it is misleadingly simple to write off the Menexenus' characterization of the Athenian politeia as purely pointless humor. ${ }^{37}$ Again, comparison with Thucydides indicates a possible context. Pericles, of course, does not call Athens an aristocracy; but he, too, says only that Athens is called by name a democracy, not that it is in truth one. Moreover, he claims that those who rank highest in the city do so not on the basis of wealth but on the basis of areté (2.37.1). His position seems unlike Socrates' only in its lack of frankness in acknowledging that democracy is only a name and in his flattering (not to mention self-serving) endorsement of the city's judgments about the virtue of its choices. Thucydides comments on (and silently endorses) the lack of candor in Pericles' epitaphios in his praise of Pericles' leadership. Under Pericles' rule, he says, Athens was at her greatest (2.65.5); and while he ruled, Athens "became in speech, on the one hand, a democracy, but in deed, on the other, a city under the rule of its first man (egigneto te logō men dēmokratia, ergō de hupo tou prōtou andros archē) $)^{\prime \prime}(2.65 .9-10)$. Plato differs from Thucydides here in two major respects: (1) in setting forward a concept of natural fitness, rather than one of civic greatness, as a starting point for estimating the character and value of a polity ${ }^{38}$ and (2) in preferring a style of playful semicandor in public oratory to one of deceptive solemnity.

\section{THE EPITAPHIOS, PARTS 2 AND 3: ATHENIAN MILITARY HISTORY AND ITS LESSONS (239A-49C)}

The natural goodness of the Athenian stock having been stated and elaborated, Socrates' Aspasian speech next moves, following tradition, to present an account of how "our forefathers, raised in freedom, have shown all human beings, both in private and in public (kai idia kai demosia), many and noble deeds, believing that it was necessary to fight for freedom with Greeks against Greeks and against barbarians on behalf of all of Hellas" (239a5-b2). This introduction to the recounting of Athenian military history connects that history with a perceived need to defend the Athenian regime. The Athenians are fighting not for glory but for isonomia (equity) and the right to choose the best and wisest among them as their leaders; Socrates also explicitly both recalls and effaces the line between public and private drawn by Pericles. Public deeds are due no special merit in the Socratic/ Aspasian account; and in the highly detailed narrative that follows, it becomes easy to see why. After saying that it is unnecessary to recall in bare prose (psiloi logoi) the mythic wars against the Amazons, Cadmians, and Argives, since these erga (deeds) have already been celebrated in poetry and music, the epitaphios goes on to say something about the three major wars of the past one hundred years-the Persian, the Peloponnesian, and the Corinthian-in prose that is very bare indeed.

Various commentators ${ }^{39}$ have noticed that Socrates' history involves some systematic distortions. Some of these were not unusual for fourthcentury Athenian patriots, such as falsely minimizing the contributions of any other Greek city, especially Sparta, to the Persian War (Thermopylae is not even mentioned); but others harder to explain, such as his 
almost suggesting that Athens was allied with Sparta against Persia in the Corinthian War, rather than the other way around. There are also striking omissions, one particularly large: Socrates tells the history of fifth-century Athens without mentioning the Athenian Empire at all, let alone celebrating the daring exploits of Athenian adventurers, à la Thucydides. The speech not only relegates Salamis to second place in importance, behind Marathon, among the battles of the Persian War, but treats Salamis, along with Marathon, merely as indications that Greeks could defend themselves against Persians-leaving aside the extraordinary character of the sea battle at Salamis, stressed by Thucydides and by Lysias, namely, that it showed the Athenian polis to be entirely separate from the Athenian earth and the Athenian regime to be located entirely in the spiritedness of Athenian citizens. ${ }^{40}$ From Plato's account, one would never know that the Peloponnesian War was in any way related to the fear of Athenian hegemony in Greece. The cause of the unexpectedly terrible character of the war, we are told, was the jealously of the rest of Greece (243b).

Not only does Plato's epitaphios deflate the grandeur of Athenian successes, it similarly plays down, in comparison with Thucydides' account, the dramatic despair inherent in the defeat of the Sicilian expedition. ${ }^{41}$ Socrates' explanation of the collapse makes it appear a passing inconvenience: "Since our polis was blocked by distance from reinforcing the fleet, bad luck made them give up their plans" (243a3-5). The speech thus manages to convey neither prowar nor antiwar sentiments. Bad luck and low motives conspired to produce undeserved defeats for the Athenians; but just as victories like Marathon and Salamis are treated as wholly instrumental to preserving freedom, rather than as memorable in themselves, ${ }^{42}$ so nothing about any of these defeats or sufferings in war seems memorable. Perhaps the clearest thing to be said about Socrates' Aspasian account of the rise and fall of the Athenian Empire is that it is an antitragic one. This can be seen by comparing the Menexenus on the defeat at Syracuse with Thucydides' account: "This was the greatest Hellenic deed (ergon) that took place during this war, and, in my opinion, the greatest that we have heard of among the Greeks-to the victors the most brilliant (lamprōtaton) and to the vanquished the most calamitous." 43 From the perspective of the Menexenus, discussion of the goodness of Athens must concern the naturalness of its regime, not the astonishing beyond-good-and-evil greatness of its military exploits. The stasis that caused the final Athenian defeat by the Spartans is treated not as a tragic disintegration of civic spirit but as notable primarily for the gentleness and moderation shown by the returning democrats to their oligarchic enemies (something Aristotle remarks on, as well, in the Constitution of Athens) owing, the speech says, to their common membership in the autochthonous Athenian genos (244a1-3). Once the stasis was concluded, Athens, for what we cannot doubt are excellent reasons, resolves never again to fight in the cause of the freedom of Hellenic xenoi, either against other Greeks or against barbarians. Unfortunately, Sparta decides to take this opportunity to enslave other Greeks.

The account of the ensuing Corinthian War $(244 \mathrm{~d}-$ $46 a)$ is similarly confused and prosaic. No pattern or ordered meaning arises here any more than from the account of the other greater wars. Everyone begs for Athens's help; and, being, as always, too compassionate (244e3), Athens is once again at war-with Sparta and in aid of Persia in spite of the fact that the Athenians, as unmixed Greeks, hate barbarians more than any other Greek does (245c6-d2). Nonetheless, it is Athenians who free the Persian king and drive the Spartans from the seas $(245 \mathrm{e}-46 \mathrm{a})$, bringing us to peace at last and to this epitaphios. Socrates' summing up of the deeds of Athenian men of war is as equivocal as the formless narrative itself: "Now many and noble deeds of the men lying here and of others who died for the city have been told, yet many more and nobler are those which have not been mentioned; for many days and nights would not be enough if one wanted to relate all of them" (246a5-b2). If the speech ended on this note, we would surely say that Socrates has managed to find an epitaphios logos guaranteed not to leave the audience feeling large and semnos for an instant, let alone three days.

The particular successes and failures of Athenian military endeavor, shorn of greatness and brilliance, provide no point of reference for future action. The ability to make war is necessary if a city is to retain its freedom, and this calls for courage in the face of danger and difficulty; but the deeds of war have nothing of Thucydidean greatness about them, and their chronicle is thus appropriately boring and repetitious. This difference can be seen by placing side by side the moral lessons drawn from the erga in the Periclean account and that of the Menexenus:

By giving their bodies for the common good, these men win for themselves praise that never ages, and the most significant (episēmotaton) of sepulchres, not the one they lie in here, but that one in the opinion of men where they leave behind their everlasting memory, always there to inspire both word and deed at the critical moment. (Thucydides 2.43.2)

Therefore it is necessary that every man, remembering these men, exhort their children, just as in wartime, not to leave the rank (taxis) of their ancestors, nor to yield to wretchedness (kakon) and make a retreat. And I myself, o children of these good men, I both exhort you now and will remind and call on you whenever I meet any of you in the future to be eager to be the best you can be. (Menexenus 246b2-c2)

The immortality stressed in Thucydides drops out in Plato; and the lesson taught by the deeds of the war dead shifts from a standing inspiration to future heroism to a reminder of the importance of keeping your place in the hoplite phalanx and of trying at all times-not just in the pressure-filled kairos (critical moment)-to live the best life you can.

But the speech does not end here (as several other 
epitaphioi do) but goes on not only to console the audience but to advise them on how to live their lives. Here, Plato's aspiration to match and exceed the scope of Pericles' oration is evident. J. E. Ziolkowski, in his survey of the funeral orations, notes that "the exhortation to the audience in Thucydides and Plato is not only longer, but also of a different nature from that of the other funeral speakers. The significant difference is that the other speakers include no advice for future action as Thucydides and Plato do. ... Even between the latter two there is an important difference: Thucydides gives directions for personal conduct in the present war; Plato gives general advice for conduct in war and peace" (1981, 159-60). The tone of the epitaphios shifts markedly at $246 \mathrm{~b} 2,44$ as the speech leaves behind the business of recounting the zigzag fates of war and turns to the task of reminding and exhorting the audience to be eager to excel in virtue. It is at this point that the concealment of the speaker's voice is extended yet one more stage, and Aspasia asks us to hear her voice as if it were the combined voice of the dead heroes. The prosopopoeia, unlike Pericles' speech, does not call on the survivors to try to match the virtue of the dead by an all-embracing erotic commitment to Athens; nor does it hold out to them the promise of immortal life as part of the undying memory of Athenian greatness. Instead, the living are urged to do better than the dead and to do so in a truly extraordinary but thoroughly Platonic way-by interpreting the Delphic motto Méden agan (nothing in excess) to mean that one's virtue depends wholly on oneself and that one ought to treat life and death lightly and moderately:

The ancient saying Méden agan seems nobly said, and it truly is well said. For that man who makes everything that concerns his eudaimonia (happiness), or most of it, rest on himself and not on other human beings (so that his own good and bad do not perforce wander up and down with theirs), that man is the one best prepared to live; and it is he who is sophron (moderate) and manly and wise, it is he who while gaining or losing wealth or children will be especially persuaded by the proverb, because he neither rejoices nor mourns overmuch, since he trusts himself. ... We ask both fathers and mothers to live the remainder of their lives holding to this same thought (dianoia), and to know that it is not by mourning and lamenting us that they will especially please us. . . . They would gratify us most by bearing [their sorrows] lightly (kouphōs) and with measure (metriōs). (247e5-48c2)

The epitaphios concludes with Aspasia resuming her own voice, asking children to listen to their dead fathers, and assuring parents of dead sons that the city will nourish their old age and care for them, repeating again the phrase "both in private and in public" (kai idia kai dēmosia, 248e4), previously used to describe the noble deeds of Athenians (239b1). She ends by reminding her audience of the political centrality of epimeleia and therapeia (the polis appearing here in the image of Nurse, rather than, as with Pericles, the magically compelling Beloved). Socrates draws the curtain on this make-believe epitaphios by reminding his audience that he has been listening to a female foreigner: "That is the logos, o Menexenus, of Aspasia the Milesian" (249d1-2). Promising not to break confidence, Menexenus asks Socrates to tell him more. Promising that we have not heard the last word, Plato has his Socrates end the drama by assuring us, "Well, these things will be done."

\section{CONCLUSION: EARTHLY IMMORTALITY AND THE GOOD LIFE}

The playfulness of the written Platonic dialogue makes it an inappropriate vehicle for setting out policy proposals or even unambiguous and systematic theories of government. But this does not mean that Plato's intervention in the political life of Athens is without point. In the dialogue, Plato sets in motion a way of talking about political life that both recalls and challenges Thucydidean political discourse, giving political life a different aim and different problems to solve. Perhaps the clearest way of expressing the challenge to Periclean morality asserted by the Menexenus is to say that it tries to direct attention away from earthly immortality and political greatness and toward a concern with living the life we have as well as possible, asking us to take our bearings in politics from our nature, rather than from a narrative of remarkable events. Part of this challenge calls for a revaluation of the Periclean distinction between public and private life, between the brilliantly noble and the merely good. The Menexenus may thus be said to carry on a project begun in the Gorgias. In that dialogue, Socrates comes closest to touching Callicles in a long speech in which he advises him not to be concerned with oratorical success or with not dying: "For anyone who is truly a man will ignore the length of time he will live and not set his soul's desire on that; but leaving all that to the god and trusting the women, who say that no one can flee his destiny, he must inquire about this thing: In what way will he best live whatever life he has?" (512d8-e5). Our worries about personal security are to be shifted not to an identification with sublime public greatness but toward inquiry concerning the good for each of us.

But why does Socrates connect that key admonition with the apparently superfluous remark that the real anēr (man) will trust women and forget about immortality? Here we may glimpse the significance of Aspasia in Plato's political philosophy. The gendering of the political voice that makes the Menexenus such an unsettling dialogue from the outset (Why does Socrates say the epitaphios is Aspasia's and not admit to its authorship himself, as Menexenus, joined by generations of commentators, so clearly wants him to do?) derives from Plato's interest in bringing to light questions and issues that Pericles and Thucydides relegate to the silence of the private life and in calling our attention to the fact that this is precisely what he is doing. Plato's Aspasia is no more a woman or less a fiction than his Diotima ${ }^{45}$ (or, for 
that matter, his Socrates); but the mask of gender, and the aporia such gendering may produce, is central to the ironical rhetoric of Plato's philosophical politics. That rhetoric is designed not directly to replace how politicians speak about the world but to incline them toward self-critical reflection about that way of speaking. Socrates' place, like that of the true politikos described in the Statesman, is not at the front of the assembly or the Bouleterion but by the edge of the agora, weaving sense into the language of political deliberation.

\section{Notes}

A version of this paper was presented at the 1991 annual meeting of the Southern Political Science Association, Tampa, Florida. For helpful comments, I thank panel organizer David Schaefer and fellow panelists Patrick Powers and Michael Zuckert.

1. Menexenus is the agreeable and playfully eristic young companion of Lysis in the Lysis and is said to have been present at Socrates' death in the Phaedo.

2. I will assume that Socrates refers here to the famous oration recorded in Thucydides' Peloponnesian War (2.35-46). This is the opinion of most scholars, though some have thought it might refer to some other Periclean oration. Several important parallels between the two speeches are good evidence for seeing the speech in the Menexenus as a response to the one in Thucydides. Kahn (1963) makes a strong case for this position. According to Socrates, the part of the epitaphios he is about to recite that was not glued together was improvised by Aspasia on the spot, with an eye to what had to be said. There are parallels here with Thucydides' account of how he composed the speeches he presents in the Peloponnesian War, that is, partly from previously written sources and partly on the basis of what he thought appropriate (1.22).

3. Thucydides says that his speeches aim at capturing what must have been said on each occasion (1.22).

4. In the Gorgias Socrates, calling himself the true politikos, says that he could never make a persuasive speech in front of an Athenian jury $(521 d-22 a, c)$.

5. The exhortation (paramuthia) to attend to the excellence of one's own way of life is similar to the prodding of Socrates the gadfly in the Apology. As for the reference to Athens as a democratic aristocracy, recall that even in Republic 8, the democracy is said to be the one regime that contains all species of regimes (557d4). Moreover, the Republic, which for Vlastos expresses "Plato's normal view of the credo of democracy in this middle period of his life" $(1973,192)$, defines democracy as that regime in which the citizens share power equally and in which public offices are filled for the most part by lot $^{\prime \prime}(8.557 \mathrm{a} 2-5)$. But this implies that to the extent that offices are filled by election, rather than lot, as is the office of public funeral orator, the regime is not, strictly speaking, a democracy but moves in the direction of aristocracy. While a demos or plèthos can never become philosophic (6.494a4), it is not impossible to exhort (paramuthoumenos) a plethos to be open to philosophy, since it, unlike the oligoi (the few), is by nature gentle (praon), rather than harsh (6.499d10-500a7)even if Adeimantus does not quite think so. In the Laws, the Athenian Stranger argues that it is easier to bring about the best regime from some forms of democracy than from an oligarchy (4.710e3-6). And in the Statesman, the Eleatic Stranger says that living in a lawless democracy is better than living in a lawless oligarchy or monarchy (303b). As Socrates says to his old friend in the Crito, the many are capable neither of great goods or great evils (44d).

6. Dodds calls the Menexenus a satyr play appended to the end of the tragic Gorgias (1959, 23-24).

7. For a survey of the controversy from antiquity to the present, see Clavaud 1980, 15-77. The ancient commentators tended to regard the dialogue as a serious epitaphios. Cicero, for example, says that it was recited every year at Athens (Orator 151). Since the eighteenth century, modern scholarly opinion has been largely on the side of a comic reading. There have, as with other perplexing dialogues, been claims that the dialogue must be spurious; but the ancient testimonies (including references to the dialogue in Aristotle's Rhetoric) make this way of solving the problem of reading the dialogue less attractive than usual. The most common way of handling the dialogue is to classify it as genuine but trivial.

8. Thucydides 2.24 . See also Isocrates, Panegyricus 74, written about 380 в.C.

9. J. E. Ziolkowski (1981) provides a most useful catalogue of genre characteristics, along with some suggestive consideration of individual differences among the speeches.

10. Nicole Loraux's 1974) is the best version of this view. She reads the dialogue as a countercharm designed to perform a katharsis on those whose self-image has been charmed into passive narcissism by uncritical paeans to Athens like Pericles' epitaphios. The difficulty with treating the dialogue as sheer parody is evident in the following characterization by Gregory Vlastos: "And just in case we have forgotten how foreign to Socrates' nature is this kind of performance, almost his last words before beginning the speech are that he will be 'playing' (236c) and 'dancing' (236d)" $(1973,190)$. But this is absurdly to assume that Socrates never characterizes his own seemingly serious speech as playful. (For an important example relating to the "seriousness" of his critique of democracy, see Republic 7.536c1-4.) It is also to forget or ignore Socrates' statement in Phaedrus that all written logoi are a kind of playing (275c).

11. Coventry's (1989) version of this point of view is worth reading, as is Henderson 1975. For a less persuasive and more extreme version, see Stern 1974. But Coventry assumeswrongly on my view - that Plato's political goal is to found a city like Kallipolis and that Menexenus is a bitter response to the failure of Athens to adopt anything like that goal.

12. For Kahn (1963), the dialogue is an attempt to rebut Periclean imperialism and reorient Athenian public opinion in the direction of Panhellenism (a position not unlike Isocrates') by recalling the old days of Greeks united against Persians at Marathon. For Loraux (1974), Menexenus is a countercharm aimed at breaking the spell-binding powers of Periclean rhetoric and freeing Athenians from the passive narcissism such rhetoric induces. For Clavaud (1980), the dialogue is a more generalized attack on the excesses of contemporary Athenian rhetoric, particularly as influenced by the teaching of Antiphon.

13. As for ambiguity, the speech leaves us with no clear precepts about the duties of citizenship and seems to baffle any attempt to be certain that Socrates' words are unequivocal, that they mean exactly what they say. But this feature is common to the whole Platonic-Socratic enterprise. For a strong and comprehensive argument for the essential and intentional ambiguity of the language of the dialogues, see Desjardins 1990. See the Phaedrus 276d-e on the essential playfulness of good written speeches.

14. I share Peter Euben's view that Thucydides "extends and elaborates Periclean foresight and that his theory embodies the virtues of Periclean leadership. In this sense Thucydides' political theory is modeled on Pericles' words and wisdom, though the latter cannot simply be a model for it since one is a speaker in the assembly whereas the other is a writer on events that took place there" $(1990,191)$. Thus, Pericles is constrained to call Athens a democracy, while Thucydides can say that it was a democracy only in word, while in deed it was, while Pericles was general, ruled by its stalwart first aner (man), not by the wavering demos (2.65.9 10). Nothing matters more to either Pericles or Thucydides than civic greatness, and it was under Pericles that Athens was at her greatest (2.65.5).

15. For instances of nature or human nature understood as a problem, rather than a solution, in Thucydides, see 3.20 (Cleon), 3.45 (Diodotus), 3.82 and 85 (Thucydides on stasis [stagnation] at Corcyra), and 5.105 (the Athenians at Melos). 
16. Whereas Isocrates' Panegyricus or Lysias' Epitaphios for example, could be so considered. It is similarly misleading to treat the Menexenus as, in effect, a "political pamphlet," as Kahn (1963) does. Plato's intentions and style are less straightforward than those of the epitaphiast or pamphleteer, though Kahn is surely right to assert the importance of placing the dialogue in the context of political debate at Athens in the early fourth century.

17. See Phaedrus 276d1-8 on the noble playfulness of the written speeches that the person who knows about the just, the good, and the beautiful sets down "as reminders for himself when he comes to the forgetfulness of old age, and for all others who follow the same path [or track, ichnos] with him." Plato calls into question a number of central dichotomies: seriousness and play, philosophy and politics, logos and mythos.

18. In terms of another of Socrates' self-characterizations, the Menexenus might be seen as a demonstration of his practice of the matchmaking techne (Theaetetus 149d-50a).

19. On the confusion surrounding the dramatic date of the Gorgias, see Dodds 1959, 17-18.

20. The situation here is thus quite different from that in the Crito, the one dialogue in which the Platonic Socrates presents an Athenian political speech (that of the personified Laws of Athens) of comparable breadth.

21. This formulation is taken from Leo Strauss $(1968,209$ $10)$. In his debate with Alexandre Kojève, Strauss says that as soon as the philosopher becomes more committed to a solution than to the continual awareness and restatement of the fundamental problems, he ceases to be a philosopher and becomes a sectarian, something Socrates never did. Strauss's distinction between philosophers and sectarians applies with special force to the philosophical politics of the Menexenus.

22. In the Philebus, there is an intriguing exchange between Philebus, Socrates, and young Protarchus, concerning the dispute between the two older men as to whether the life of nous, or mind, is preferable to the life of pleasure. Responding to Socrates' praise of nous, Philebus says, "You puff up (semnuneis) your own god, Socrates" (28b1). After a few lines, Socrates asks Protarchus if he has disturbed him by "playfully puffing up (semmunōn en tō paidzen) nous" (28c2). Protarchus says that his is at a loss; and Socrates responds that "all the wise agree-thus puffing themselves up (heautos ontōs semnunontes) - that nous is our king over heaven and earth. And perhaps they speak well" (28c6-8). The importance of the verb semnoo for Socrates' critique of epitaphioi will be apparent in $\mathbf{n}$. 28. Stanley Rosen calls attention to the importance of this passage $(1991,161)$. But Rosen radicalizes and distorts the passage by ignoring both Socrates' reference to play and the nasty edge Socrates gives to semnoo (which Rosen translates as "exalt").

23. This is the way Philip Manville characterizes the agora $(1990,194)$. Notice, however, that Socrates is very far from the otherworldly philosopher whom Socrates describes in the Theaetetus, who does not even know the way to the agora.

24 . On the council, see Ober 1989, 138-41.

25. Thucydides remarks on the long-standing custom of the public epitaphios while introducing Pericles' speech (2.34), as does Isocrates (Panegyricus 74); and all the surviving speeches, including Socrates' and Pericles', open by acknowledging its traditional character.

26. Coventry calls attention to the importance of this passage $(1989,1-2)$, as does Méridier in his Budé edition of the dialogue, where he aptly comments on it as follows: "In a strict sense, the epimeletes were distinct from ordinary magistrates (archontes) in that they acted only on instructions given by the people (for example, ambassadors, customs officials, public works commissioners). But here, as often with Plato, the word is taken in a general sense" $(1931$, vol. 5, pt. 1, 83-84n).

27. Compare the bewitching effect of the speech of the Laws of Athens on Socrates at the end of the Crito (54d2-7). Both are logoi that put an effective stop to the possibility of any future logoi. This is emphatically not the case with the ironic epitaphios of the Menexenus, which not only permits, but demands, further commentary and interpretation.

28. Semnos and semnotēs can have a positive meaning, suggesting "holy, august, reversed, majestic." Context makes it likely that Socrates does not intend this, but we can never be sure. Socrates uses a related word, the verb semnoo, in the Gorgias when describing a truly useful techne, that of the ship's pilot. Unlike the useless orator, the pilot does not puff himself up (ou semnunetai, Gorgias, 511d4)

29. Meno 80a-b, 94e. Just as Socrates charges in the Menexenus that epitaphiasts bewitch their audience into a helplessly semnos condition, so Meno uses the same verb (goèteuein) in charging Socrates with bewitching his interlocutors into helpless aporia $(80 \mathrm{a} 1-4)$. This is what leads Loraux (1974) to see the Menexenus as a Platonic countercharm against the patriotic drug of orations like Pericles'.

30. That the politikos could meet the orators on their own ground seems to be impossible, at least in a law court, according to the true politikos of the Gorgias 521d-22a.

31. Ziolkowski 1981, 65. Socrates has remarked to Menexenus that nothing could be easier than finding ways of praising Athens and Athenians before an Athenian audience (236a).

32. Pericles says that his speech can be heard with profit by both Athenians and xenoi (Thucydides 2.36.4).

33. See, e.g., the speech of the Athenians at the first Spartan Congress (ibid. 1.74).

34. Autochthony and nourishment by the motherland is also mentioned (though with much less emphasis) later in the fourth century by Demosthenes (Epitaphios 5).

35. Stories about the gods and their intervention in human affairs are, for Thucydides, relics of the outdated Homeric tradition of Greek history he hopes to supersede. Socrates' attitude toward divine mythology, as he explains it to young Phaedrus, is that since he has to spend all his time trying to know himself, he has no leisure left for working out secular explanations for events popular belief credits to the gods and so is perfectly willing to leave popular mythology alone (Phaedrus 229e-30a).

36. See the citations collected in n. 5. Recall particularly that democracy for Plato is a generic type that admits of a greater variety of instantiations than either tyranny or oligarchy and for the Athenian Stranger in the Laws, the best regime can more easily be achieved in transition from a relatively good democracy than from any sort of oligarchy. According to the definitions of democracy and oligarchy in Aristotle's Politics 3, of course, the institution of election by vote, so central a feature of political life in fifth and fourth century Athens, is an aristocratic characteristic; pure democrats choose their leaders by lot, oligarchs by wealth.

37. It is likewise misleading to write it off as simple parody, as in Vlastos's characterization of "the primped-up Athens of 'Aspasia's' speech" $(1973,195)$.

38. Thucydides' references to nature and to human nature almost always suggest anticivic tendencies, rather than any possible basis for nomos. For example, according to Cleon, human beings are naturally inclined to feel contempt toward those who serve them, while for Diodotus, human beings individually and in cities are naturally inclined to injustice (3.39.45). The Athenians at Melos say that by nature, both gods and humans rule wherever they can (5.105). Thucydides comments on the wretchedness of unchecked human inclinations in his own voice in his discussion of the stasis at Corcyra, and later in the same discussion says that human phusis aims at overturning human nomos (3.82.84). The only reference to nature as providing an appropriate standard for evaluating conduct is in regard to women. For example, Pericles, at the end of his epitaphios, says that women should follow their nature and stay out of public life (2.45.2); and Thucydides tells of women taking an active part against their nature (para phusin) in the fighting at Corcyra (3.74.1-2). Unlike women, real men for Thucydides must aim at transcending and controlling nature. Another roughly contemporary instance of phusis used as a standard only for women is to be found in the telling of the story of the war with the Amazons in Lysias (Epitaphios 4). 
39. My discussion here relies on Kahn 1963 and, esp, Henderson 1975.

40. Compare Plato's brief mention of the battle of Salamis with the ecstatic account given by the Athenians at the first Spartan Congress in Thucydides 1.74, and with Lysias, Epitaphios 32-46.

41. Henderson notes this $(1975,42)$.

42. Compare Lysias: "By means of many toils, shining contests, and most beautiful hazards, they made Greece, on the one hand, free, and their own fatherland, on the other, surpassingly great". (Epitaphios 55 ).

43. Thucydides 7.87 .

44. This is noted by both Henderson (1975) and Coventry (1989).

45. On the reason for inventing a woman as Socrates' instructor in erotics (the one art he calls his own), see Halperin 1990. Aspasia's role as Socrates' instructor in the art of political oratory reinforces, I believe, Halperin's commentary on Diotima.

\section{References}

Clavaud, Robert. 1980. Le "Menexène" de Platon et al rhétorique de son temps. Paris: Belles Lettres.

Coventry, Lucinda. 1989. "Philosophy and Rhetoric in the Menexenus." Journal of Hellenic Studies 109:1-15.

Desjardins, Rosemary. 1990. The Rational Enterprise: Logos in Plato's "Theaetetus." Albany: State University of New York Press.
Dodds, E. R. 1959. Plato: Gorgias. London: Oxford University Press.

Euben, J. Peter. 1990. The Tragedy of Political Theory. Princeton: Princeton University Press.

Halperin, David M. 1990. "Why Is Diotima a Woman? Platonic Eros and the Figuration of Gender." In One Hundred Years of Homosexuality. New York: Routledge.

Henderson, M. M. 1975. “Plato's Menexenus and the Distortion of History." Acta Classica 18:25-46.

Kahn, Charles. 1963. "Plato's Funeral Oration: the Motive of the Menexenus." Classical Philology 220-34.

Loraux, Nicole. 1974. "Socrate contrepoison de l'oraison de funèbre." L'antiquité classique 43:172-211.

Loraux, Nicole. 1986. The Invention of Athens: the Funeral Oration in the Classical City. Trans. Alan Sheridan. Cambridge: Harvard University Press.

Manville, Philip. 1990. The Origins of Citizenship in Ancient Athens. Princeton: Princeton University Press.

Méridier, Louis, ed. 1931. Plato: Oeuvres Complètes. Paris: Les Belles Lettres.

Ober, Josiah 1989. Mass and Elite in Democratic Athens. Princeton: Princeton University Press.

Rosen, Stanley. 1991. "Leo Strauss and the Quarrel Between the Ancients and the Moderns." In Leo Strauss's Thought, ed. Alan Udoff. Boulder: Lynne Rienner.

Stern, H. S. 1974. "Plato's Funeral Oration." New Scholasticism 48:503-08.

Strauss, Leo. 1968. On Tyranny. Ithaca: Cornell University Press.

Vlastos, Gregory. 1973. Platonic Studies. Princeton: Princetion University Press.

Ziolkowski, J. E. 1981. Thucydides and the Tradition of Funeral Speeches at Athens. Salem: Arno.

Stephen G. Salkever is Professor of Political Science, Bryn Mawr College, Bryn Mawr, PA 19010-2899. 